\title{
Pemahaman Konsep Matematika Siswa SMP Melalui Pendekatan Realistic Mathematics Education
}

\author{
Nur Fauziah Siregar ${ }^{1}$ \\ ${ }^{1}$ Program Studi Pendidikan Matematika, Fakultas Tarbiyah dan Ilmu Keguruan, IAIN Padangsidimpuan \\ Jl. T. Rizal Nurdin No. Km 4, Sihitang, Padangsidimpuan Tenggara, Sumatera Utara \\ nurfauziah125@gmail.com
}

\begin{abstract}
The importance of understanding the concept of mathematics is seen from the objectives in learning mathematics that must be achieved by students in accordance with the 2013 curriculum. Mathematics is a subject that is difficult for students to understand for some students. Learning with the Realistic Mathematics Education approach is learning that brings students into direct experience through real learning with everyday life. By learning the Realistic Mathematics Education approach can better influence students' understanding of mathematical concepts. This study aims to determine the effect of applying the Realistic Mathematics Education approach to the understanding of the mathematical concepts of students of SMP Negeri 7 Padangsidimpuan. This type of research is quasi-experimental. The study population was all class VIII SMP Negeri 7 Padangsidimpuan. The research sample was taken randomly as many as 2 classes. The research instrument used a test, with the test used a valid and reliable test. Data analysis was performed by $t$ test. The results showed that there was an effect of applying the Realistic Mathematics Education approach to the understanding of the mathematical concepts of the students of SMP Negeri 7 Padangsidimpuan. Learning Realistic Mathematics Education approaches to understanding mathematical concepts is better than conventional learning.
\end{abstract}

Keywords: Realistic Mathematics Education Approach, Concept Understanding, mathematics

\begin{abstract}
Abstrak
Pentingnya pemahaman konsep matematika dilihat dari tujuan dalam pembelajaran matematika yang harus dicapai siswa sesuai dengan kurikulum 2013. Matematika merupakan mata pelajaran yang sulit dipahami siswa bagi sebagian siswa. Pembelajaran dengan pendekatan Realistic Mathematics Education merupakan pembelajaran yang membawa siswa kedalam pengalaman langsung melalui pembelajaran nyata dengan kehidupan sehari-hari. Dengan pembelajaran pendekatan Realistic Mathematics Education dapat mempengaruhi pemahaman siswa terhadap konsep-konsep matematika dengan lebih baik. Penelitian ini bertujuan untuk mengetahui pengaruh penerapan pendekatan Realistic Mathematics Education terhadap pemahaman konsep matematika siswa SMP Negeri 7 Padangsidimpuan. Jenis penelitian quasi eksperimen. Populasi penelitian adalah seluruh kelas VIII SMP Negeri 7 Padangsidimpuan. Sampel penelitian diambil dengan secara acak sebanyak 2 kelas. Instrumen penelitian dengan menggunakan tes, dengan tes yang digunakan tes yang valid dan reliabel. Analisis data dilakukan dengan uji t. Hasil penelitian menunjukkan bahwa terdapat pengaruh penerapan pendekatan Realistic Mathematics Education terhadap pemahaman konsep matematika siswa SMP Negeri 7 Padangsidimpuan. Pembelajaran pendekatan Realistic Mathematics Education terhadap pemahaman konsep matematika lebih baik daripada pembelajaran konvensional.
\end{abstract}

Kata kunci: Pendekatan Realistic Mathematics Education, Pemahaman Konsep, Matematika

Copyright (c) 2021 Nur Fauziah Siregar

$\triangle$ Corresponding author: Nur Fauziah Siregar

Email Address: nurfauziah125@gmail.com (J1. T. Rizal Nurdin No. Km 4, Sihitang, Sumatera Utara)

Received 18 May 2021, Accepted 22 May 2021, Published 12 Juli 2021

\section{PENDAHULUAN}

Matematika merupakan bagian dari komponen serangkaian mata pelajaran yang mempunyai peranan penting dalam pendidikan. Matematika berperan penting dalam berbagai disiplin dan memajukan daya pikir manusia (Nunes, T., \& Bryant, 2020). Matematika merupakan salah satu bidang studi yang mendukung dan mempengaruhi perkembangan ilmu pengetahuan dan teknologi. Dengan kata lain, matematika adalah bekal bagi peserta didik untuk berpikir logis, analitis, sistematis, kritis dan kreatif. Sebagai bahasa simbolis, ciri 
utama matematika ialah penalaran secara deduktif namun tidak mengabaikan cara penalaran induktif. Selain sebagai bahasa simbolis, matematika juga merupakan ilmu yang kajian objeknya bersifat abstrak (Sundayana, 2013).

Matematika banyak dipergunakan dalam kehidupan sehari-hari. Proses pembelajaran matematika yang sistematis, sehingga dalam pembelajaran siswa memiliki pemahaman awal untuk lanjut pada level yang lebih tinggi. Dalam belajar matematika, bukan hanya capaian bertambah materi yang dibutuhkan siswa, tetapi bagaimana penguasaan dan pemahaman matematika yang telah dipelajari, terutama pada kemampuan pemahaman konsep. Hal ini dikarenakan pemahaman konsep matematika merupakan akar atau dasar menuju penguasaan konsep matematika lainnya yang lebih tinggi atau serta menunjang kemampuan koneksi antara konsep tersebut (Zulnaidi, H., \& Zakaria, 2012).

Pentingnya pemahaman konsep matematika terlihat dalam tujuan pertama pembelajaran matematika yaitu dalam kurikulum 2013 dinyatakan bahwa pembelajaran siswa harus memiliki seperangkat kompetensi Matematika sebagai barikut: Pemahaman konsep, Penalaran, Komunikasi, Pemecahan masalah, Memiliki sikap menghargai kegunaan Matematika dalam kehidupan (D, 2011). Pemahaman konsep perlu ditanamkan kepada peserta didik sejak dini masih duduk di bangku sekolah dasar. Siswa memiliki kemampuan untuk memahami tentang defenisi, pengertian cara pemecahan masalah maupun pengoperasian matematika secara benar. Hal tersebut akan menjadi bekal dalam mempelajari matematika pada jenjang pendidikan yang lebih tinggi (Herawati, 2010).

Berdasarkan Badan Standar Nasional Pendidikan (BNSP) dalam model penilaian kelas pada satuan SMP menyebutkan indikator-indikator yang menunjukkan pemahaman konsep antara lain:

1. Menyatakan ulang sebuah konsep, yaitu kemampuan siswa untuk mengungkapkan kembali apa yang telah dikomunikasikan kepadanya baik lisan maupun tulisan.

2. Mengklasifikasikan objek menurut sifat-sifat tertentu sesuai dengan konsepnya, yaitu kemampuan siswa untuk dapat mengelompokkan objek menurut sifat-sifatnya.

3. Memberi contoh dan non contoh dari konsep, yaitu kemampuan siswa dapat membedakan contoh dan bukan contoh dari suatu materi yang telah dipelajari.

4. Menyajikan konsep dalam berbagai bentuk representasi matematis, yaitu kemampuan siswa menggambar atau membuat grafik, membuat ekspresi matematis, menyusun cerita atau teks tertulis.

5. Mengembangkan syarat perlu atau syarat cukup dari suatu konsep, yaitu kemampuan siswa mengkaji mana syarat perlu atau syarat cukup suatu konsep yang terkait.

6. Menggunakan, memanfaatkan, dan memilih prosedur tertentu, yaitu kemampuan siswa menyelesaikan soal dengan tepat sesuai dengan prosedur.

7. Mengaplikasikan konsep atau algoritma pemecahan masalah, yaitu kemampuan siswa menggunakan konsep atau prosedur tertentu.

Susanto di dalam Fadhila menyatakan kemampuan pemahaman konsep merupakan kemampuan siswa untuk dapat mengerti konsep yang diajarkan guru. Lebih lanjutnya menurut Fadhila kemampuan siswa dalam menjelaskan konsep yang telah dipelajari dengan menggunakan kata-kata sendiri (Fadhila El 
Husna, 2014). Pemahaman konsep dapat diartikan sebagai karakteristik seseorang dalam memaknai suatu pemahaman dengan pikiran dan pandangan yang benar (Bella Tika Pramesti, 2020). Penguasaan siswa terhadap materi matematika, dimana siswa siswa tidak hanya mengetahui tetapi memiliki kemampuan untuk dapat menjelaskan kembali sebuah konsep dengan menggunakan bahasa dan kalimat siswa sendiri serta dapat menggunakannya merupakan kemampuan pemahaman konsep matematika yang dimiliki siswa.

Siswa sering sekali mengalami kesulitan untuk mengumpulkan informasi dari sebuah pernyataan yang diberikan, hal ini disebabkan karena kurangnya pemahaman siswa dalam mengolah informasi. Siswa dihadapkan dengan masalah yang berbeda-beda, sehingga diharapkan dengan penerapan pendekatan pembelajaran siswa mampu menyelesaikan masala-masalah yang ada, agar siswa semakin mahir dalam memecahkan masalah dengan menggunakan kemampuan pemahaman konsep. Dalam penelitian Jeheman, Gunur, \& Jelatu menyatakan bahwa pemahaman konsep matematika yang baik belum sepenuhnya sampai pada seluruh pebelajar saat ini. Beberapa fakta di sekolah yang secara khusus ditemukan menunjukkan bahwa kondisi ideal yang diharapkan tentang pemahaman konsep masih kurang. Beberapa siswa masih menganggap matematika sulit dan tak bermakna (Jeheman, Gunur, 2019). Sejalan dengan yang ditemukan peneliti pada kelas VIII di SMP Negeri 7 Padangsidimpuan masih terdapat siswa yang masih kurang terhadap kemampuan pemahaman konsep matematika siswa berdasarkan hasil penyelesaian masalah dari soal yang berdasarkan indikator pemahaman konsep.

Proses pembelajaran konvensional seperti pembelajaran yang berpusat pada guru kurang efektif dalam mencapai pemahaman konsep yang optimal. Oleh karena peran guru merupakan aspek sentral untuk mencapai tujuan pemahaman konsep, maka dalam konteks pembelajaran matematika yang kekinian, guru mesti berpandangan bahwa materi-materi matematika bukanlah sebuah materi hafalan, namun lebih dari itu, yaitu memahami konsep dari apa diberikan (Jehadus, 2018). Dari hasil kajian Badan Penelitian dan Pengembangan Departemen Pendidikan Nasional tahun 2007, diperoleh beberapa permasalahan yang terjadi di setiap jenjang pendidikan dasar dan menengah, diantaranya yaitu 1) Pelaksanaan pembelajaran di kelas masih konvensional; 2) Metode pembelajaran kurang bervariasi, umumnya masih ceramah dan tanya jawab; dan 3) Kegiatan belajar mengajar kurang mengaktifkan siswa. Aktivitas siswa yang cenderung pasif berdampak pada pencapaian pemahaman konsep matematika kurang memadai mengakibatkan pencapian hasil belajara siswa yang kurang memuaskan (Nasional, 2007).

Pembelajaran yang dilakukan harus menekankan kepada aktivitas siswa sehingga memungkinkan siswa untuk lebih aktif dalam belajar dan mengembangkan potensi yang dimiliki. Diperlukan inovasi pembelajaran yang tepat dan sesuai dengan kebutuhan siswa yang berkaitan dengan masalah kehidupan nyata, sehingga siswa tidak hanya mengetahui, tetapi juga dapat menemukan suatu konsep yang mereka pelajari melalui pengalaman belajar nyata. Melihat hal tersebut, Sehingga diperlukan pendekatan pembelajaran yang sesuai. Salah satunya adalah pendekatan pembelajaran Realistic Mathematics Education (RME). Siti dkk dalam penelitiannya Pengaruh Pendekatan Realistic Mathematics Education (RME) terhadap Kemampuan Pemahaman Matematis dan Kepercayaan Diri Siswa pada Materi Menyederhanakan Pecahan. Sedangkan Penelitian sebelum ini penulis telah mengembangkan modul matematika terintegrasi 
nilai-nilai keislaman melalui pendekatan Realistic Mathematics Education (RME) di Provinsi Riau. Sehingga berdasarkan penelitian tersebut penulis dapat menyimpulkan bahwa pendekatan RME ini dapat mempengaruhi kemampuan pemahaman konsep matematis siswa (Siti Nur'aini, 2016). RME dikembangkan berdasarkan pandangan tentang bagaimana siswa belajar Matematika dan bagaimana Matematika diajarkan. Realistic Mathematics Education (RME) merupakan pembelajaran yang memadukan antara konsep secara teoritis yang sama atau seimbang dalam realitis kehidupan. Konsep dapat direalisasikan dalam kehidupan sebagai fakta nyata.

Soedjadi menyatakan PMR pada dasarnya adalah pemanfaatan realita dan lingkungan yang dipahami peserta didik untuk memperlancar proses pembelajaran matematika sehingga mencapai tujuan pendidikan matematika secara lebih baik daripada masa lalu (Soedjadi, 2001). PMR berpandangan bahwa matematika adalah kegiatan manusia. Eksplorasi ide, konsep, masalah nyata merupakan aktifitas kelas matematika (Soviawati, 2011). Pembelajaran yang bermula pada permasalahan nyata yang berorientasi antara konsep matematika dengan konteks permasalahan dunia nyata, dengan menggunakan keterampilan dengan cara berkolaborasi dalam berdiskusi.

Untuk menerapkan Realistic Mathematics Education (RME) yang menggunakan kegiatan nyata disekitar siswa dapat diimajinasikan siswa sebagai titik awal dalam memahami suatu konsep matematika. Melalui pendekatan Realistic Mathematics Education, pembelajaran diawali dengan masalah kontekstual, sehingga siswa menggunakan pengalaman sebelumnya secara langsung. Pendekatan RME dan Pendekatan kontekstual merupakan pendekatan pembelajaran yang berbeda. Pendekatan RME hanya memuat penggunaan konteks, siswa berkontribusi dengan intrumen merupakan kegiatan yang interaktif dalam keterkaitan topik dengan pembelajaran, sedangkan pendekatan kontekstual memuat penggunaan konstruktivisme dengan penemuan melalui kegiatan masyarakat belajar yang diikuti dengan kegiatan bertanya, pemodelan dan adanya refleksi dalam pembelajaran dengan pemberian nilai nyata dalam belajar. Dalam pembelajaran dengan pendekatan RME, siswa belajar dengan dapat memanfaatkan benda-benda yang ada disekitarnya, misalkan penggaris, pinsil, pulpen, penghapus, buku dan lain sebagainya. Bendabenda tersebut dapat dijadikan sebagai alat dalam memahami variabel, koefisien, konstanta, persamaan linier dua variabel dan system persamaan linier dua variabel. Proses penyajian materi dari konsep yang sesuai dari situasi nyata dinyatakan sebagai matematisasi konsep. Pembelajaran matematika realistic melibatkan siswa secara langsung dalam memahami matematika sehingga dapat meningkatkan kemampuan dalam memahami matematika. Melalui pengalaman langsung, siswa melakukan proses penemuan kembali, yang dikembangkan melalui penyelesaian berbagai masalah matematika dalam kehidupan sehari-hari yang berada dilingkungan sekitar (Siregar, 2016).

Prinsip-prinsip pokok pembelajaran matematika pada PMR yang dikemukakan oleh Marpaung; 1) Prinsip Aktivitas, 2) Prinsip Realita, 3) Prinsip Penjenjangan, 4) Prinsip Jalinan, 5) Prinsip Interaks, 6) Prinsip Bimbingan. Pembelajaran yang didominasi dengan aktivitas siswa yang dimulai dari masalahmasalah dunia nyata dengan penyelesaian dari menemukan penyelesaian secara kontekstual baik dilakukan 
secara individu dan berkelompok berdasarkan peran guru sebagai fasilitator dan sebagai pembimbing siswa dalam menyelesaikan berbagai permasalahan matematika (Marpaung, 2003).

Strategi yang dikembangkan dan diciptakan dalam pembelajaran dilakukan dalam bentuk matematika formal seperti konsep dan algaritma yang telah siswa pelajari sebelumnya. Interaksi antara siswa dan guru memperdalam pemahaman terhadap konsep matematika. Siswa diarahkan untuk berfikir, merespon, berdiskusi, mengelaborasikan, menulis, membaca, mendengarkan serta menemukan konsep - konsep matematika sehingga siswa dapat memahami suatu konsep materi matematika.

Melalui pendekatan Realistic Mathematics Education diharapkan dapat memberikan solusi dan suasana yang menarik dalam pembelajaran matematika sehingga memudahkan siswa memahami materi yang diajarkan dan hasil belajar siswa berkembang. Pembelajaran pendekatan Realistic Mathematics Education memberikan kesempatan kepada siswa untuk menemukan kembali pengetahuan dengan memanfaatkan kesempatan dan situasi nyata yang dialami oleh siswa, memberikan efek terhadap kemampuan pemahaman konsep matematika siswa dari pengalaman belajar langsung.

\section{METODE}

Jenis penelitian ini adalah penelitian kuantitatif dengan metode quasi eksperimen. Penelitian ini metode eksperimen digunakan untuk mencari Pengaruh Realistic Mathematics Education (RME) Terhadap Pemahaman Konsep Matematika Siswa. Bentuk desain yang digunakan dapat dilihat pada tabel berikut ini:

Tabel 1

(Pretest-Posttest Control Group Design)

\begin{tabular}{|l|l|l|l|}
\hline Kelompok & Pretest & Perlakuan & Posttest \\
\hline Eksperimen & $\mathrm{T}_{1}$ & $\mathrm{X}$ & $\mathrm{T}_{2}$ \\
\hline Kontrol & $\mathrm{O}_{1}$ & - & $\mathrm{O}_{2}$ \\
\hline
\end{tabular}

Populasinya adalah seluruh siswa kelas VIII SMPN 7 Padangsidimpuan, sebanyak 5 kelas. Sampel dikelompokkan ke dalam dua kelas, yang dijadikan kelas eksperimen adalah kelas VIII-2 sebanyak 22 siswa dan kelas kontrol adalah kelas VIII-4 sebanyak 22 siswa. Kelas eksperimen diberikan pembelajaran dengan menggunakan model pembelajaran Realistic Mathematics Education (RME) sedangkan kepada kelas kontrol proses pembelajaran seperti biasanya yang digunakan guru matematika.

Instrumen pengumpulan data dalam penelitian ini adalah tes. Tes yang dilaksanakan berbentuk tes subyetif untuk pemahaman konsep siswa terhadap materi Sistem Persamaan Linear Dua Variabel. Tes subjektif yang digunakan peneliti merupakan ter tertulis yaitu essay tes. Sebelum tes ini diberikan kepada kelompok sampel penelitian, terlebih dahulu diuji validitas soal dan reliabilitas soal, melalui menguji cobakan kepada kelas lain yang bukan sampel penelitian. Berdasarkan hasil coba instrumen diperoleh instrumen yang valid dan reliabel. Syarat dari validitas adalah Suatu item dikatakan valid jika nilai $r_{\text {hitung }}>r_{\text {tabel }}$ dan jika $r_{\text {hitung }}<r_{\text {tabel }}$ maka itemnya tidak valid. Sedangkan Untuk menentukan reliabilitas soal uraian menggunakan rumus Alpha Cronbach. 
Analisis data yang digunakan dalam penelitian ini adalah analisis dekskriptif dan analisis inferensial. Untuk analisis data awal digunakan uji normalitas, homogenitas, dan uji perbedaan rata-rata. Pengujian hipotesis yang digunakan adalah dengan menggunakan rumus " $t$ tes". Test " $t$ " adalah salah satu test statistik yang dipergunakan untuk menguji kebenaran atau kepalsuan hipotesis nihil yang menyatakan bahwa diantara dua buah mean sampel yang diambil secara random dari populasi yang sama, tidak terdapat perbedaan yang signifikan (Sudjiono, 2010).

$$
t=\frac{\overline{x_{1}-\overline{x_{2}}}}{s a b \sqrt{\frac{1}{n 1}+\frac{1}{n 2}}}
$$

\section{HASIL DAN PEMBAHASAN}

Deskripsi data Kemampuan Pemahaman Konsep siswa adalah data hasil Pre-Test dan Post Test yang berisi tentang kondisi awal nilai kemampuan pemahaman konsep siswa kedua kelompok (Eksperimen dan Kontrol) sebelum dan sesudah diberi treatment (Perlakuan). Dari hasil deskripsi data pre tes ditunjukkan bahwa pada kelas eksperimen diperoleh mean 59 termasuk ke dalam kategori baik. Pada kelas eksperimen dan kelas kontrol tertinggi yang sama. Berdasarkan rata-rata Pretest dapat dilihat bahwa kedua kelas berawal dari titik tolak yang sama dengan rata-rata kelas eksperimen dan kelas kontrol yaitu 59. Hal tersebut dapat ditunjukkan oleh hasil uji-t data awal dimana $t_{\text {hitung }}=0,871<t_{\text {tabel }}=2,021$, artinya kedua kelas berangkat dari yang kondisi awal sama.

Setelah pembelajaran selesai, kedua kelompok diuji dengan post test pemahaman konsep pada materi pokok sistem persamaan linear dua variabel. Dari hasil post test yang didapatkan di kelas eksperimen, ada siswa yang memperoleh nilai 100 dan nilai terendah 68, serta mean 89. Dari data tersebut dapat dinyatakan setelah perlakukan pembelajaran Realistic Mathematics Education (RME) ada perubahan yang terjadi diperoleh dari nilai siswa. Sedangkan di kelas kontrol diperoleh nilai terendah 55, dan nilai tertinggi 95 serta mean 79. Pada kelas kontrol juga mengalami perubahan dari hasil pre tes dan post test. Dari kedua kelas tersebut yang lebih dominan dapat mempengaruhi hasil pemahaman kosnsep siswa pada materi sistem persamaan linear dua variabel adalah pada kelas ekspremen. Di kelas eksperimen siswa memiliki nilai post test dibawah rerata ada 2 siswa, sedangkan dikelas kontrol ada 9 siswa.

Berdasarkan uji persyaratan data nilai awal (Pre-Test) dan data nilai akhir (Post Test) diperoleh hasil data berdistribusi normal dan homogen. Pengujian kenormalan distribusi kedua kelompok digunakan uji chi kuadrat, data yang diuji adalah rata-rata pre-test dan rata-rata post-test. Diperoleh $X^{2}$ hitung < $X^{2}$ tabel, maka Ho diterima. Sehingga dapat dikatakan kedua kelas tersebut berdistribusi normal.

Diperoleh $F_{\text {hitung }}=1,113$ dan $\mathrm{F}_{\text {tabel }}=2,10$ dapat dilihat bahwa $F_{\text {hitung }} \leq F_{\text {tabel }}$ berarti Ho dapat diterima. Dengan demikian dapat diketahui pada data awal dari kedua kelas tersebut mempunyai varians yang sama (homogen). Sedangkan pada data nilai akhir diperoleh hasil kesimpulan yang sama yaitu kedua 
kelas tersebut mempunyai varians yang sama. $\mathrm{F}_{\text {hitung }}=1,41$ dan $\mathrm{F}_{\text {tabel }}=2,10 F_{\text {hitung }} \leq F_{\text {tabel }}$, berarti Ho diterima.

Untuk menguji hipotesis digunakan uji-t, uji perbedaan dua rata-rata yang menentukan pengaruh pendekatan Realistic Mathematics Education terhadap pemahaman konsep siswa dengan materi sistem persamaan linier dua variabel. Dari perhitungan terlihat bahwa $t_{\text {hitung }}=11,395>t_{\text {tabel }}=2,021$. Dari perhitungan penolakan $H o$ dan penerimaan $H_{1}$. Dengan demikian $H_{1}: \mu_{E}>\mu_{K}$ diterima, artinya rata-rata pemahaman konsep siswa pada pokok bahasan Sistem Persamaan Linear Dua Variabel dengan pendekatan Realistic Mathematics Education ada pengaruh. Dapat disimpulkan bahwa ada pengaruh pendekatan Realistic Mathematics Education terhadap pemahaman konsep matematika siswa SMP N 7 Padangsidimpuan.

Berdasarkan kesimpulan hasil penelitian bahwa ada pengaruh pendekatan Realistic Mathematics Education terhadap pemahaman konsep matematika pada materi system persamaan linear dua variabel siswa kelas VIII SMP N 7 Padangsidimpuan. Kesimpulan penelitian ini didukung oleh pendapat Arnida Sari dan Suci Yuniati yang menyatakan bahwa penerapan pendekatan Realistic Mathematics Education siswa lebih mudah meyerap pelajaran dan menyelesaikan soal dengan baik (Yuniati, 2018). Pada PMR, aktifitas pembelajaran diawali dengan menggali pengalaman-pengalaman siswa dalam kesehariaanya (masalah yang kontekstual) (Jeheman, Gunur, 2019). Pembelajaran Realistic Mathematics Education memberikan kesempatan kepada siswa untuk dapat kembali mengkontruksikan konsep-konsep matematika dengan mengaitkan dunia nyata, memberikan pengaruh yang luar biasa terhadap pengetahuan dan pemahaman yang kuat tentang konsep-konsep matematika.

Pembelajaran dengan pendekatan Realistic Mathematics Education dilakukan dalam proses belajar dengan mengaitkan kehidupan sehari-hari yang siswa ketahui, sehingga lebih mudah dan aktif dalam menyelesaikan pembelajaran, hal ini dikarenakan konsep dasar pembelajaran sesuai dengan pengetahuan awal siswa. Hasil penelitian ini juga mendukung penelitian Samuel (dalam Gomez) yang menyatakan bahwa kreativitas bukanlah datang dengan mudah melalui bakat alami seseorang, melainkan melalui suatu usaha dan waktu dengan melibatkan pengalaman terkait kreativitas dalam suatu project (Gomez, 2007). Sejalan dengan hasil penelitian Muhtadi \& Sukirwan bahwa peningkatan kemandirian belajar peserta didik yang mendapat pembelajaran matematika realistik lebih baik daripada peserta didik yang mendapat pembelajaran konvensional (Sukirwan, 2017).

Pembelajaran dengan menggunakan pendekatan matematika realistik dapat membuat: 1. Matematika lebih menarik, relevan, dan bermakna, tidak terlalu formal dan tidak terlalu abstrak. 2. Mempertimbangkan tingkat kemampuan siswa. 3. Menekankan belajar matematika pada 'learning by doing'. 4. Memfasilitasi penyelesaian masalah matematika tanpa menggunakan penyelesaian (algoritma) yang baku. 5 . Menggunakan konteks sebagai titik awal pembelajaran matematika (MKPBM, 2003). Siswa belajar lebih bermakna dengan pengalaman langsung yang diberikan guru melalui masalah nyata atau kontektual, sebagai titik awal siswa untuk dapat memahami konsep-konsep matematika dengan menerapkan 
pengetahuan awal siswa berdasarkan tingkat kemampuan siswa. Siswa dapat melibatkan dirinya dalam kegiatan belajar dan konteks dapat menjadi alat untuk pembentukan konsep, dimulai dengan suatu hal yang bersifat kontekstual dan dekat dengan siswa, maka siswa dapat mengembangkan sendiri model matematika (Mikke Novia Indriani, 2018).

\section{KESIMPULAN}

Siswa yang memiliki konseptual yang baik, dapat dinyatakan siswa memiliki kemampuan memahami, dapat mengaplikasikan serta dapat memodifikasi suatu konsep dalam menyelesaikan masalah matematika. Pembelajaran yang mengantarkan siswa dapat menerapkan kemampuan pemahaman konsep matematika melalui pendekatan Realistic Mathematics Education. Berdasarkan hasil penelitian bahwa terdapat pengaruh pendekatan Realistic Mathematics Education terhadap pemahaman konsep matematika siswa SMP Negeri 7 Padangsidimpuan. Dengan demikian dapat dinyatakan bahwa pembelajaran dengan pendekatan Realistic Mathematics Education lebih baik daripada pembelajaran konvensional.

\section{REFERENSI}

Bella Tika Pramesti, H. L. M. (2020). Analisis Pemahaman Konsep Peluang Siswa SMP Ditinjau Dari Teori APOS. Jurnal Cendekia: Jurnal Pendidikan Matematika, Volume 04(N0.2), 1054-1063.

D, J. A. (2011). Analisis Kurikulum Matematika. Jakarta: Universitas Terbuka.

Fadhila El Husna, F. D. dan D. M. (2014). Penerapan Strategi REACT dalam Meningkatkan Kemamupan Pemahaman Konsep Matematika Siswa Kelas X SMAN 1 Batang Anai. Jurnal Pendidikan Matematika, Volume 3(No. 1).

Gomez, J. G. (2007). What Do We Know about Creativity?. Journal of Effective Teaching, Volume 7(No. 1), 31-43.

Herawati, O. D. P. (2010). Pengaruh Pembelajaran Problem Posing Terhadap Kemampuan Pemahaman KonsepMatematika Siswa Kelas XI IPA SMA Negeri 6 Palembang. Jurnal PendidikanMatematika, Volume VII (Edisi 9).

Jehadus, E. (2018). Model Quantum Untuk Mengatasi Kecemasan. Jurnal Pendidikan Dan Kebudayaan Missio, Volume 10(No. 2), 137-142.

Jeheman, Gunur, \& J. (2019). Pengaruh Pendekatan Matematika Realistik terhadap Pemahaman Konsep Matematika Siswa. Mosharafa: Jurnal Pendidikan Matematika, Volume 8(No. 2).

Marpaung. (2003). Pendekatan Sosio Kultural dalam Pembelajaran Matematika dan Sains, et al. Pendidikan yang Humanistis. Yogyakarta: Kanisius.

Mikke Novia Indriani, I. (2018). Pembelajaran Matematika Realistik Dalam Permainan Edukasi Berbasis Keunggulan Lokal Untuk Membangun Komunikasi Matematis. In Prisma, Prosiding Seminar Nasional Matematika. UNNES.

MKPBM, T. (2003). Strategi Pembelajaran Matematika Kontemporer. UPI Bandung: JICA.

Nasional, D. P. (2007). Kajian Kebijakan Kurikulum Mata Pelajaran Matematika. Jakarta: Badan 
Penelitian dan Pengembangan Pusat Kurikulum Depdiknas.

Nunes, T., \& Bryant, P. (2020). Learning and Teaching Mathematics, An International Perspective. UK: Psychology Press.

Siregar, N. F. (2016). Pemahaman dan Komunikasi Matematis dalam Pembelajaran Matematika Realistik. Jurnal Logaritma, Vol. IV (No. 1).

Siti Nur'aini, R. I. dan J. (2016). Pengaruh pendekatan realistic mathematics education (RME) terhadap Kemampuan Pemahaman Matematis dan Kepercayaan Diri Siswa pada Materi Menyederhanakan Pecahan. Jurnal Pena Ilmiah, Volume 1(No. 1), 691-700.

Soedjadi, R. (2001). Pemanfaatan Realitas dan Lingkungan dalam Pembelajaran Matematika. In Seminar Nasional Realistic Mathematics Education. FMIPA UNESA.

Soviawati, E. (2011). Pendekatan Matematika Realistik (PMR) untuk Meningkatkan Kemampuan Berfikir Siswa di Tingkat Sekolah Dasar. Jurnal Penelitian Pendidikan, Edisi Khus.

Sudjiono, A. (2010). Pengantar Statistik Pendidikan. Jakarta: Rajawali Press.

Sukirwan, M. \&. (2017). Implementasi Pendidikan Matematika Realistik (PMR) Untuk Meningkatkan Kemampuan Berpikir Kreatif Matematik Dan Kemandirian Belajar Peserta Didik. Jurnal Mosharafa, Volume 6(No. 1).

Sundayana, R. (2013). Media dan Alat Peraga dalam Pembelajaran Matematika. Bandung: ALFABETA. Yuniati, A. S. dan S. (2018). Penerapan Pendekatan Realistic Mathematics Education (RME) Terhadap Kemampuan Pemahaman Konsep Matematis. Jurnal Cendekia: Jurnal Pendidikan Matematika, Volume 2.

Zulnaidi, H., \& Zakaria, E. (2012). The Effect of Using GeoGebra on Conceptual and Procedural Knowledge of High School Mathematics Students. Asian Social Science, 8(11), 102-106. 